\title{
Peran Komunikasi dalam Implementasi Kebijakan Pelacakan Kontak Erat dan Pemantauan Isolasi Mandiri Penderita Covid-19 Oleh Puskesmas di Kota Palembang
}

\author{
Dian Hayati*, Misnaniarti, Haerawati Idris \\ Program Studi Magister Kesehatan Masyarakat, Universitas Sriwijaya \\ *Correspondence email: dr.dianazhan@gmail.com
}

\begin{abstract}
Abstrak. Melakukan pelacakan kontak erat dan segera menisolasi kasus dan kontak, merupakan mitigasi terpilih untuk mengimbangi dampak terhadap ekonomi dan sosial akibat dari pandemic covid-19. Analisis implementasi kebijakan pelacakan kontak erat dan pemantauan isolasi mandiri ini merupakan tahapan penting untuk masukan berbagai pihak untuk menentukan kebijakan yang lebih baik di masa mendatang sehingga pandemi dapat segera berakhir. Maka diperlukannya komunikasi yang baik antara pihak yang terkait dalam implementasi kebijakan tersebut. Penelitian ini adalah penelitian kualitatif dengan desain deskriptif yang bertujuan untuk mengetahui peran komunikasi dalam implementasi kebijakan pelacakan kontak erat dan pemantauan isolasi mandiri oleh Puskesmas di Kota Palembang tahun 2020 yang dapat dilihat dari variabel transmisi, kejelasan dan konsistensi menggunakan Teori Edward III. Metode pengumpulan data dilakukan dengan wawancara mendalam, observasi dan telaah dokumen. Hasil penelitian didapatkan bahwa kurangnya sosialisasi yang dilakukan terkait dengan pedoman pencegahan maupun pelacakan kontak dan isolasi mandiri penderita covid-19, tidak efektifnya sosialisasi pedoman yang dilakukan secara virtual, serta terjadi ketidakkonsistenan dalam pelacakan kontak dikarenakan beberapa faktor yang pertama ketidakjujuran pasien, stigma masyarakat, data rilis kasus terlambat, alamat/ nomor telpon tidak jelas, pasien tidak kooperatif serta perubahan pedoman yang terjadi dari revisi 4 ke revisi 5. Saran dari penelitian ini adalah agar melakukan evaluasi mengenai sosialisasi pedoman, meningkatkan pengetahuan dan kemampuan implementor, meningkatkan koordinasi dan kerjasama implementor, pemberdayaan peran masyarakat sehingga mengurangi stigma di masyarakat.
\end{abstract}

Kata kunci: Covid-19; Komunikasi; Kontak Erat; Isolasi Mandiri

\begin{abstract}
Carrying out close contact tracing and immediately isolating cases and contacts, is the chosen mitigation to offset the economic and social impact of the COVID-19 pandemic. This analysis of the implementation of the close contact tracing policy and monitoring of self-isolation is an important step for input from various parties to determine better policies in the future so that the pandemic can end soon. So good communication is needed between the parties involved in implementing the policy. This study is a qualitative research with a descriptive design that aims to determine the role of communication in the implementation of close contact tracing policies and self-isolation monitoring by the comunnity health centers in Palembang City 2020 which can be seen from the transmission, clarity and consistency variables using Edward III Theory. Methods of collecting data were in-depth interviews, observation and document review. The results of the study found that the lack of socialization carried out related to guidelines for prevention and contact tracing and self-isolation of COVID-19 sufferers, the ineffectiveness of socialization of guidelines carried out virtually, as well as inconsistencies in contact tracing due to several factors, firstly patient dishonesty, community stigma, data late case release, unclear address/telephone number, uncooperative patient and changes in guidelines that occurred from revision 4 to revision 5. Suggestions from this study are to evaluate the socialization of guidelines, increase knowledge and abilities of implementors, improve coordination and cooperation of implementers, empowerment of community roles so as to reduce stigma in society.
\end{abstract}

Keywords: Covid-19; Communication; Close Contact; Self Isolation

\section{PENDAHULUAN}

Coronavirus Disease2019 (COVID-19) adalah penyakit menular yang disebabkan oleh virus Severe Acute Respiratory Syndrom eCorona virus2 (SARSCoV-2) yang belum pernah diidentifikasi sebelumnya pada manusia (Lu et al., 2020). Penyebarannya sangat cepat sehingga walaupun CFR $(3,4 \%)$ lebih rendah dari pada Middle East Respiratory Syndrome( MERS) CFR (34\%) dan Severe Acute Respiratory Syndrome (SARS) CFR (10\%), jumlah total angka kematian COVID-19 sampai 16 Oktober 2020 yaitu 1.095.097 jiwa sedangkan kematian akibat SARS yang berakhir pada tahun 2003 yaitu 774 kematian dan MERS pada tahun 2012 dan
2019 sebanyak 858 kematian (World Health Organization, 2019).

Indonesia melaporkan kasus pertama pada tanggal 2 Maret 2020. Kasus terus meningkat dan menyebar dengan cepat di seluruh wilayah Indonesia. Berdasarkan data dari Gugus Tugas COVID-19 Indonesia, angka penularan terus meningkat, mulai dari bulan Maret Juli total kasus konfirmasi berturut-turut sejumlah 1.577 orang, 95.451 orang, 106.287 orang dan 108.376 orang. Dengan total kasus sampai 16 Oktober di Indonesia yaitu 353.461 orang dan Sumatera Selatan 7.056 orang. Angka mortalitas di Indonesia mencapai 12.347 orang dengan CFR 3,5 \%, lebih tinggi dibandingkan dengan CFR global yaitu 2,8\% (Kemenkes RI, 2020). 
Berbagai kebijakan sebagai upaya untuk pencegahan penularan COVID-19 telah dilakukan negara-negara di dunia. Pencegahan penularan diterapkan melalui penguncian negara (lockdown) diantaranya yaitu China, yang merupakan negara yang menerapkan karantina terbesar dalam sejarah manusia dalam upaya pengendalian virus, diikuti juga oleh Italia, Spanyol, Perancis, Malaysia, dan Filipina. Lockdown dilakukan dengan penundaan dan pembatalan acara besar didunia, penutupan tempat-tempat wisata dan tempat perdagangan, penerbangan internasional serta seluruh sekolah dan universitas (Dorigatti et al., 2020). Indonesia sendiri mengambil kebijakan Pembatasan Sosial Berskala Besar (PSBB).

Pelaksanaan lockdown telah terbukti dapat menurunkan morbiditas dan mortalitas, tetapi berdampak pada kemerosotan ekonomi dan sosial apabila dilaksanakan dalam jangka waktu lama. Banyak negara telah melakukan pelonggaran terhadap lockdown, dan penambahan kasus kembali terjadi. Seperti india, dalam satu bulan setelah pelonggaran lockdown, menjadi negara ketigakasus COVID-19 tertinggi didunia (WHO, 2020f)

Konsekuensi terhadap penanggulangan COVID19 yang diperkirakan akan menyebabkan resesi ekonomi dunia, mendorong berbagai negara didunia untuk mengubah strategi penanggulangan dengan mengkarantina dan isolasi yang lebih selektif melalui pelacakan kontak. Pelacakan kontak adalah manajemen wabah penyakit menular terbaik, yang bertujuan untuk memutus rantai penularan infeksi melalui karantina kontak, telah menjadi bagian dari respon terhadap pandemi COVID-19 di banyak negara. Singapore merupakan salah satu negara dengan pelacakan kontak erat yang efektif menurunkan penyebaran kasus tanpa mengalami dampak ekonomi dan sosial yang serius, karena ditunjang oleh kebijakan ketat yaitu menugaskan petugas pelacak terlatih, penggunaan tehnologi, kebijakan hukuman untuk pemberian informasi palsu saat pelacakan kontak dan hukuman apabila melakukan pelanggaran karantina/isolasi mandiri (Lee, Chiew, \& Khong, 2020).

Menurut WHO, tantangan dalam pelacakan kontak yaitu identifikasi kontak yang tidak lengkap, ketidakefisienan dalam sistem pelaporan berbasis kertas, persyaratan manajemen data yang kompleks, dan keterlambatan dalam langkah-langkah dari identifikasi kontak hingga karantina/isolasi kontak. Diperlukan strategi dalam sisitem kesehatan masyarakat yang optimal dan pemanfaatan sumber daya yang mencakup petugas layanan kesehatan, layanan testing, dan infrastruktur maupun tehnologi canggih untuk melaksanakan pelacakan kontak yang efektif (WHO, 2020c).

Kebijakan Pelacakan Kontak erat dan pemantauan karantina kontak/isolasi COVID-19 di Indonesia tertuang melalui Keputusan Menteri Kesehatan Nomor
HK.01.07/MENKES/413/2020 tentang Pencegahan dan Pengendalian Coronavirus Disease (COVID-19). Pedoman ini merupakan revisi dari pedoman serupa yang diterbitkan pada 16 Maret 2020 dengan perubahan pada beberapa substansi sesuai perkembangan situasi dan pengetahuan. Perubahan yang terkait dengan pelacakan kontak dan pemantauan isolasi mandiri yaitu pada perubahan pemeriksaan RT-PCR yang pada pedoman revisi 4 dilakukan pada semua kontak erat sedangkan pada revisi 5 hanya dilakukan pada kontak yang bergejala saja (suspect), kontak eratbukan hanya terbatas pada kontak kasus konfirmasi tetapi dengan kontak kasus probable baik yang masih hidup maupun yang telah meninggal, dan pernyataan bebas isolasi mandiri diberikan tanpa harus dikonfirmasi dengan pemeriksaan RT-PCR. Pedoman ini merupakan revisi ke 5 dari pedoman pertama yang diterbitkan oleh Kementrian Kesehatan RI tentang Pedoman Kesiapsiagaan Menghadapi Corona Virus Disease (COVID-19).

Kota Palembang, melaporkankasus COVID-19 pertama kali pada bulan April 2020, dan kasus terus meningkat sampai dengan 10 Oktober 2020 total kasus sebanyak 3197 orang dan kematian sebanyak 192 orang. Kota Palembang termasuk daerah transmisi lokal dan terdapat kasus cluster dan merupakan penyumbang kasus terbesar di antara kabupaten/kota di Propinsi Sumatera Selatan. Terdapat 41 Puskesmas yang tersebar di 18 kecamatan di Kota Palembang. Sesuai dengan pedoman Penanggulangan COVID-19 Kementrian Kesehatan RI, pelacakan kontak dilakukan dengan cara manual oleh petugas surveilans Puskesmas di seluruh Indonesia. Puskesmas melakukan pelacakan kontak dan pemantauan isolasi mandiri berdasarkan prinsip pertanggungjawaban wilayah. Puskesmas akan melaksanakan pelacakan kontak dan pemantauan isolasi mandiri sesuai dengan alamat tempat tinggal kasus index.

Kebijakan Pelacakan kontak erat dan pemantauan isolasi mandiri harus diimplementasikan oleh para implementor sesuai tupoksinya masing-masing. Puskesmas di seluruh Indonesia berkoordinasi dengan satgas COVID-19 tingkat kecamatan bertanggung jawab terhadap pelaksanaan dilapangan sedangkan Dinas Kesehatan Kabupaten/Kota bertanggung jawab di tingkat kota sebagai supervisor dan pencapaian tujuan dari kebijakan tersebut. Menurut Edward III untuk keberhasilan dari implemntasi suatu kebijakan di pengaruhi 4 faktor diantaranya yaitu faktor komunikasi yang dapat dilihat dari variabel transmisi, kejelasan dan konsisten.

Tantangan Puskesmas dalam pelaksanaan pelacakan konta kerat dan pemantauan isolasi mandiri antara lain adalah sebagian besar petugas pelacak dan pemantau adalah wanita sehingga mempunyai perasaan takut tertular yang tinggi, adanya kebijakan sosial distancing sehingga pelatihan petugas tidak dapat 
dilaksanakan dengan tatap muka langsung, komunikasi yang tidak efektif sehingga menyebabkan informasi tentang COVID-19 yang sampai masih rendah di masyarakat sehingga menimbulkan stigma dan ketidakpatuhan dalam pelaksanaan isolasi mandiri, dan sarana pelacakan dan pemantauan isolasi tidakd idukung oleh tehnologi canggih.

Puskesmas memiliki otoritas dalam pelaksanaan tracing dan pemantauan isolasi mandiri sehingga perluasan penyebaran COVID-19 di Indonesia menjadi tanggung jawab Puskesmas. Dalam mengimplementasikan suatu kebijakan, komunikasi yang harus diterima pelaksana kebijakan pelaksana harus jelas dan tidak membinggungkan sehingga kebijakan dapat dilaksanakan dengan baik dilapangan dan agar tujuan dari kebijakan penanggulangan COVID-19 dengan mencegah penyebaran penyakit melalui peningkatan testing, tracing dan treathment dapat segera tercapai. Sehingga ini lah yang menjadi minat peneliti untuk menganalisis peran komunikasi dalam implementasi kebijakan pelacakan kontak erat dan pemantauan isolasi mandiri penderita COVID-19 oleh Puskesmas di Kota Palembang.

\section{METODE}

Jenis penelitian ini adalah penelitian deskriptif analitik dengan menggunakan pendekatan kualitatif. Pemilihan informan pada penelitian ini menggunakan metode purposive yaitu berdasarkan pertimbangan tertentu, Jumlah sampel dalam penelitian ini sebanyak 59 informan, antara lain Ka. Dinkes Kota Palembang, Kasi Surveilans Dinkes, Ka. Puskesmas 18 orang, Petugas Surveilans Puskesmas 18 orang, Lintas sector Puskesmas tingkat kecamatan (Lurah, ketua RT, Babinsa, Babinkamtibmas) 12 orang, dan PenderitaCovid 19 yang telah selesai melaksanakan isolasi mandiri di rumah sebanyak 9 orang.

Instrument utama dalam penelitian ini adalah penelitian itu sendiri atau yang disebut Human Instrument. Apabila didapati fokus penelitian sudah cuku pjelas, maka kemungkinan akan dikembangkan instrument penelitian sederhana yang diharapkan dapat melengkapi data dan membandingkan dengan data yang telah ditentukan melalui observasi dan wawancara mendalam (indepth interview)

\section{HASIL DAN PEMBAHASAN}

Komunikasi yang efektif antara pelaksana atau implementor dengan sasaran, akan menghasilkan pelaksanaan kebijakan yang dapat dilaksanakan dengan baik. Pemahaman sasaran atas informasi yang disampaikan adalah merupakan hal yang sangat vital dalam implemetasi sebuah kebijakan. Ada tiga hal yang diteliti dalam faktor komunikasi yaitu transmisi, kejelasan dan konsistensi.

\section{Transmisi}

Proses transmisi didapatkan oleh Dinas Kesehatan Kota Palembang pertama kali dari Dinas Kesehatan Propinsi Sumatera Selatan dan Kementrian Kesehatan melalui pertemuan virtual dengan media zoom meeting dalam rangka sosialisasi pedoman penanggulangan COVID-19 revisi ketiga pada bulan April 2020. Kemudian Dinas Kesehatan mengadakan sosialisasi pertama terkait COVID-19 kepada Kepala Puskesmas yang dilaksanakan secara tatap muka pada bulan April 2020 kepada Kepala Puskesmas dan kepada petugas Surveilans Puskesmas pada bulan Mei 2020. Sosialisasi tersebut hanya berupa rapat koordinasi dan arahan dari Kepala Dinas Kesehatan tentang bagaimana menyikapi para pelaku perjalanan atau orang yang baru pulang dari luar negeri. Selanjutnya sosialisasi secara tatap muka langsung tidak dapat lagi dilaksanakan oleh Dinas Kesehatan dikarenakan kebijakan social distancing. Berikut hasil wawancara dengan Kepala Puskesmas :

“...ya sekali pertemuannya kayak rapat, gak pakai PPT atau paparan gimana ..."(P5)

“...Pernah dulu diundang ke dinas kesehatan waktu itu sekitar bulan maret apa april saya lupa...Selain kepala dinas, juga hadir kabid P2P dan kasi surveilans. Selanjutnya sosialisasi-sosialisasi yang saya ikuti secara virtual saja..." (P6).

Hasil tersebut juga didukung oleh hasil wawancara dengan petugas surveilans puskesmas :

“...Yang secara langsung waktu pertemuan surveilans beberapa bulan yang lalu. Bulan maret 2020 di awal-awal pandemi..." (P14)

“...Pada bulan 5 kasus pandemi ditetapkan, kami disuruh kumpul di dinas, petugas surveilans, sosialisasi yang waktu itu kebenaran dengan ibu kabid P2P yang langsung ngasiin sosialisasi bagaimana kesiapan tenaga surveilans menghadapi pandemi. Itu yang diawal, kalau selanjutnya soal sosialisasi pedoman-pedoman, kalau ada pertemuan kami biasanya ada webinar dari kemenkes yang mengisi acaranya...."(P15)

Kemudian peneliti mengkonfirmasi dengan Dinas Kesehatan terkait pertemuan yang diadakan secara tatap muka langsung. Menurut Dinas Kesehatan, sosialisasi saat itu harus cepat dilakukan karena puskesmas sebagai ujung tombak kegiatan pennaggulangan belum mempunyai bekal informasi terkait COVID-19 karena penyakit ini baru ditemukan. Sosialisasi ini hanya berupa rapat koordinasi untuk menguatkan puskesmas dalam menanggulangi kasus COVID-19 yang sudah mulai ditemukan di Kota Palembang. Untuk sosialisasi selanjutnya, Dinas Kesehatan tidak dapat melaksanakan secara langsung lagi karena adanya kebijakan social distancing. Berikut hasil wawancara dengan Kepala Dinas dan Kasi Surveilans : 
“...Kasus pertama itu di Palembang di akhir maret ya, jadi kita memang belum bersiap sebelumnya. Jadi kita mendadak menyiapkan diri. Belum ada aplikasi zoom meeting, Jadi waktu itu pertama kali mengundang Kepala-Kepala Puskesmas ke Dinas Kesehatan untuk mensosialisasikan bagaimana kita akan menanggulangin COVID ini. Memang bentuknya seperti rapat koordinasi yah, tidak pakai paparan, dan waktunya sangat singkat dan disambung lagi sosialisasi melalui wa grup..."(P1)

Pertemuan selanjutnya diadakan secara virtual, tetapi Dinas Kesehatan hanya meneruskan link undangan zoom meeting dari Kemenkes karena Dinas Kesehatan belum berlangganan aplikasi zoom meeting. Sosialisasi dan koordinasi dari Dinas Kesehatan terutama kepada petugas surveilans dilakukan melalui grup whatsapp.

Hasil wawancara tersebut sejalan dengan hasil observasi peneliti bahwa sosialisasi diberikan melalui zoom meeting saja.

Tabel 1. Hasil Observasi Sosialisasi

\begin{tabular}{|c|l|c|}
\hline 1 & Adanya Sosialisasi Pedoman & $\begin{array}{c}\text { sosialisasi melalui zoom } \\
\text { dan whatsapp }\end{array}$ \\
\hline 2 & $\begin{array}{l}\text { Adanya rapat koordinasi } \\
\text { dengan Dinas Kesehatan }\end{array}$ & $\mathrm{X}$ \\
\hline 3 & $\begin{array}{l}\text { Adanya rapat koordinasi } \\
\text { dengan Satgas COVID-19 } \\
\text { tingkat Kecamatan }\end{array}$ & $\mathrm{X}$ \\
\hline
\end{tabular}

Selain stakeholder yang terkait, sosialisasi ke masyarakat sudah dilakukan Dinas Kesehatan Kota Palembang melalui kantor-kantor yang terdapat kasus konfirmasi dimana dilakukan kegiatan pelacakan kontak sekaligus memberikan edukasi dan sosialisasi terkait COVID-19. Selain itu, sosialisasi kepada masyarakat intens dilakukan melalui media sosial. Hal ini terlihat dari hasil wawancara sebagai berikut :

“....Selain sosialisasi ke puskesmas, kami juga ada komunikasi dengan pihak-pihak hotel, bank, tahap awal saat mereka belum ada kasus. Yang disosialisasikan cara pencegahannya, trus kalau ada yang positif harus bagaimana. Kalau saat ini, saat kasus telah berjalan ada juga perkantoran yang ada kasus, kita juga akan datang kesana untuk pelacakan dan komunikasi risiko dan biasanya kami melibatkan puskesmas setempat..."(P1).

Meskipun sudah adanya kerjasama dengan lintas sector terkait, namun di tingkat Puskesmas, terdapat kesulitan untuk melakukan sosialisasi. Pertemuan advokasi dan sosialisasi tentang COVID-19 dengan lintas sektor dan masyarakat belum pernah dilakukan oleh Puskesmas. Sedangkan pertemuan dengan menggunakan zoom meeting tidak bisa dilakukan karena puskesmas tidak mempunyai aplikasi tersebut dan masyarakat tidak semuanya mempunyai kuota internet. Sosialisasi juga banyak dilakukan melalui grup wahtsapp kelurahan maupun grup whatsapp satgas COVID-19 tingkat Kecamatan. Selain itu sosialisasi dilakukan lewat media sosial, spanduk, brosur, dan secara mobile menggunakan ambulans dan pengeras suara.

“...Kalau sosialisasi ke ketua-ketua RT kami belum pernah secara langsung, paling lewat wa grup. Kalo mau lewat zoom gimana, mana ada masyarakatnya laptop atau android kan gak seluruhnya punya...." (P6).

“....kemudian kita akan melakukan sosialisasi kemasyarakat, mobile pakai ambulans, dan juga pakai selebaran, keliling-keliling pakai TOA...tiap hari petugas juga selalu share di medsos kita, kita ada IG ada FB...." (P7)

Hasil wawancara tersebut sejalan dengan hasil observasi yang dilakukan oleh peneliti :

Tabel 2. Hasil Observasi Penyuluhan

\begin{tabular}{|l|l|l|l|}
\hline 1 & $\begin{array}{l}\text { Adanya penyuluhan tentang } \\
\text { protokol kesehatan }\end{array}$ & $\mathrm{V}$ & \\
\hline 2 & $\begin{array}{l}\text { Adanya penyuluhan tentang } \\
\text { COVID-19, pelacakan kontak } \\
\text { dan isolasi mandiri }\end{array}$ & $\mathrm{V}$ & $\begin{array}{l}\text { Penyuluhan } \\
\text { dalam gedung } \\
\text { kepada } \\
\text { pengunjung } \\
\text { puskesmas }\end{array}$ \\
\hline 3 & $\begin{array}{l}\text { Adanya bahan promosi tentang } \\
\text { pencegahan V V } \\
\text { (Banner, poster, spanduk, } \\
\text { leaflet) }\end{array}$ & $\begin{array}{l}\text { Adanya leaflet cara melakukan } \\
\text { isolasi mandiri }\end{array}$ & $\mathrm{X}$ \\
\hline
\end{tabular}

Berdasarkan hasil penelitian tersebut diketahui bahwa kurangnya sosialisasi yang dilakukan terkait dengan pedoman pencegahan maupun pelacakan kontak dan isolasi mandiri penderita covid-19. Sosialisasi hanya dilakukan melalui zoom meeting dan group whatsapp. Hal ini jika terjadi terus menerus maka dapat menyebabkan para petugas puskesmas yang merupakan ujung tombak dalam kegiatan pelacakan kontak dan isolasi mandiri penderita covid-19 akan mengalami banyak kendala karena pedoman tersebut harus dipahami secara mandiri oleh petugas yang terkait serta terbatasnya waktu membuat petugas belum bisa memahami dan membaca hingga selesai pedoman yang ada. Kurangnya sosialisasi yang dilakukan dapat membuat petugas salah dalam mengimplementasikan kebijakan yang ada. Penyaluran komunikasi yang baik akan dapat menghasilkan suatu implementasi yang baik pula. 


\section{Kejelasan}

Kebijakan dilarang berkumpul yang diterapkan pemerintah mempengaruhi cara pelaksanaan sosialisasi. Sosialisasi melalui zoom meeting ternyata kurang efektif dibanding pertemuan tatap muka langsung. Petugas merasa lebih jelas dan lebih ingat akan materi yang disampaikan apabila pertemuan dilakukan tatap muka langsung dan pesertanya terbatas atas petugas Puskesmas Palembang saja.

Hasil wawancara dengan petugas kesehatan :

“...saya tidak ingat lagi masalah apa-apa yang saya ikuti lewat zoom. Karena membaca sendiri pedomannya, kadang petugas-petugas masih banyak bingungnya. Kalau tidak sinkron dengan dilapangan kita konsultasikan lagi dengan dinkes...." (P11).

“....Materi yang disampaikan secara detail tidak jelas yah, tapi secara garis besar cukuplah, mungkin harus cari informasi lagi sendiri atau mendownload lagi informasi-informasi itu dari google atau materinya ada dikirim...." (P9)

Setelah dikonfirmasi dengan informan Dinas Kesehatan didapatkan memang benar setelah petugas surveilans puskesmas mengikuti zoom meeting, biasanya langsung disambung dengan banyak pertanyaan dan diskusi melalui grup whatsapp. Petugas puskesmas merasa belum jelas dengan materi yang telah disampaikan melalui zoom meeting.

\section{“....Kalau untuk Puskesmas, lebih banyak kita sama- sama mempelajari materi melalui wa grup. Jadi kalau misalnya nanti kita bagikan link undangan zoom untuk diikuti oleh Puskesmas, pasti nanti masih banyak yang bingung. Makanya biasanya selesai zoom meeting, kita share lagi materi zoom meeting tadi. Biasanya kalau habis zoom meeting, banyaklah gak jelasnya, buktinya banyak surveilans puskesmas nanya lagi digrup wa besoknya, apa mereka gak sempat ikut waktu pertemuannya ya, kita kan gak tau juga....” (P2).}

Berdasarkan hasil penelitian tersebut diketahui bahwa sosialisasi yang dilakukan melalui virtual zoom meeting tidak efektif. Kemudian peneliti menganalisis lebih jauh apa yang menjadi penyebab petugas puskesmas tidak fokus sehingga tidak jelas akan materi yang disampaikan melalui zoom meeting. Dari hasil penelitian didapatkan beberapa hal yang menjadi penyebab yaitu dari segi penyelenggaraan acara, yang menjadi alasan ketidakjelasan antara lain jumlah peserta zoom meeting yang banyak membuat keterikatan dengan narasumber dan acara tidak terbangun, tidak ada peraturan dari penyelenggara untuk menghidupkan kamera sehingga bisa mengikuti zoom sambil melakukan kegiatan lainnya, dan tidak mendapatkan surat tugas khusus dari kepala puskesmas sehingga mengikuti zoom meeting sambil bekerja. Seperti yang diungkapkan oleh Kepala Puskesmas dan Petugas Surveilans berikut ini :

“...Jumlahnya sampai ratusan. Jadi kadang saya sambil-sambil lah dengan mengerjakan pekerjaan lainnya. Kadang saya hidupkan laptopnya, tapi tidak terlalu saya perhatikan... Karna saya ngerjain pekerjaan lain. Saya sering juga sambil rapat, sambil liat zoom, suaranya saya kecilin atau matikan kan bisa juga. Pura-puranya kita ikut kan?...” (P5)

Sedangkan kalau dari segi sarana yang dibutuhkan, ada beberapa kendala yang menyebabkan petugas tidak fokus sehingga tidak jelas akan materi yang disampaikan yaitu terkait harus mendownload aplikasi tersebut ke telepon seluler milik pribadi yang memorinya tidak cukup dan layar telepon seluler yang kekecilan sehingga tidak nyaman melihat paparan materi. Penyelenggaraan acara online seperti zoom meeting, tidak terbatas pada waktu dan tempat, sehingga acara dapat diikuti dari mana saja dan kapan saja. Sehingga ini menjadi kendala bagi petugas apabila diselenggarakan di luar jam kerja terkait keterbatasan kuota internet dan tidak dapat menggunakan laptop maupun komputer puskesmas.

Hasil wawancara dengan petugas puskesmas :

“...hapenya jadul bu, memorinya gak cukup mau download....” (P11)

“....kebanyakan diluar jam kerjo bu, dak mungkin kito nak dewekan dipuskes karno nak make wifi atau komputer puskes, makonyo kadang dak sampe selesai aku melok..."(P12)

Hasil wawancara tersebut sejalan dengan hasil observasi yang dilakukan oleh peneliti bahwa sosialisasi yang dilakukan kurang melalui virtual tersebut tidak efetif dikarenakan waktu yang terbatas, sarana yang kurang medukung serta banyaknya file-file yang harus didownload dan dipahami sendiri. Pedoman yang diberikan hanya pedoman pencegahan dan pengendalian covid-19 secara umum, sedangkan pedoman yang khusus membahas tentang pelacakan kontak erat dan pemantauan isolasi mandiri penderita covid-19 baru saja dikeluarkan oleh Kemenkes pada bulai Mei 2021.

Tabel 3. Hasil Observasi Pedoman pelacakan kontak dan isolasi mandiri

\begin{tabular}{|l|l|l|l|}
\hline 1 & $\begin{array}{l}\text { Adanya pedoman khusus } \\
\text { pelacakan kontak erat dan } \\
\text { pemantauan isolasi mandiri } \\
\text { penderita covid-19 }\end{array}$ & V & $\begin{array}{l}\text { Baru dikeluarkan } \\
\text { pada tanggal 11 } \\
\text { Mei 2021 }\end{array}$ \\
\hline
\end{tabular}


Pelaksanaan pelacakan kontak erat dan pemantauan isolasi mandiri penderita covid-19 dibutuhkan pedoman dan panduan yang khusus agar kegiatan tersebut dapat dilaksanakan secara masif, cepat, efektif dan terkoordinasi. Maka, pedoman tersebut harus disosialisasikan dengan baik dengan petugas yang terkait. Komunikasi yang diterima oleh pelaksana kebijakan (street-levelbureaucrats) harus jelas dan tidak membingungkan atau tidak ambigu. Sosialisasi yang dilakukan secara virtual ini akan menyebabkan banyak ketidakjelasan yang akan diterima oleh petugas yang disebabkan oleh situasi dan kondisi yang kurng mendukung. Ketidakjelasan komunikasi yang disampaikan berhubungan dengan pelaksanaan kebijakan yang dapat mendorong terjadinya interpretasi (penafsiran) yang salah bahkan kemungkinan dapat bertentangan dengan makna pesan awal yang sebenarnya.

\section{Konsistensi}

Pelaksanaan pelacakan kontak erat (tracing) dan pemantauan isolasi mandiri, Puskemas Kota Palembang mengacu pada pedoman penanggulangan COVID-19 Kemenkes RI yang semenjak bulan Agustus terbit revisi 5. Pedoman didapatkan petugas secara softcopy dan diarahkan oleh Dinas Kesehatan untuk dicetak sendiri oleh Puskesmas. Petugas Puskesmas tidak pernah mendapatkan pelatihan terkait juknis pelaksanaan kegiatan penanggulangan COVID-19 sesuai dengan pedoman. Hasil dari wawancara mendalam dengan informan Puskesmas mendapatkan hasil bahwa terjadi ketidakkonsistenan dalam pelacakan kontak yang dilakukan oleh Puskesmas. Petugas surveilans puskesmas tidak berhasil mengidentifikasi kontak erat selain kontak serumah penderita. Petugas puskesmas meminta Kartu Keluarga (KK) pasien terkonfirmasi dan mencatat anggota keluarga yang tercantum pada KK yang tinggal serumah sebagai kontak erat.

“....Data kontak yang kami dapat, biasanya tidak kami hubungi lagi, karena biasanya hanya mendapatkan data kontak serumah saja. KK nya kami mintakan..Kontak erat sekantor jarang sekali kami dapatkan, ada baru-baru ini satu kantor...." (P13)

“....Biasanya pasien ngomong cuma keluarga, jarang kami dapati kontak erat lainnya..Ada beberapa pasien itu yang kayak keberatan. Jadi mengulur-ulur sejak kami telepon dan pada akhirnya gak dikasih KK nya. Itu kalau kami tidak bisa koordinasi dengan RT, biasanya gak dapat, lost..."(P15)

Banyak kendala yang ditemui petugas surveilans sewaktu melacak kontak sehingga kasus konfirmasi tidak mau jujur dalam mengungkap kontak eratnya.
Selain karena memang faktor memori dari penderita, dengan alasan sudah lupa atau tidak ingat lagi riwayat perjalanan dan kegiatan penderita mulai dari 2 hari sebelum timbul gejala sampai 14 hari. Namun ada juga karena faktor stigma sehingga penderita tidak mau orang yang dikenal atau tetangga tempat tinggal mengetahui status penderita. Orang lebih takut dengan pandangan orang sekitar dari pada penyakitnya sendiri. Penderita juga tidak mau disalahkan oleh kontak erat karena telah mengungkap identitas mereka sehingga mereka juga akhirnya harus melakukan isolasi.

Hasil wawancara dengan petugas kesehatan :

“....kalau kontak erat yang tidak serumah, itu jarang sekali bisa kami dapatkan datanya. Bisa kadang ribut besar antara si kasus dan kontak eratnya..Orang lebih takut dengan pandangan masyarakat sekitarnya daripada dengan penyakit covid itu sendiri..." (P15)

“...Tapi kenyataannya dilapangan, kalau orang yang kami tracing itu, selalu ngomongnya kami tidak kemana-mana. Cuma sama keluarga saja. jadi kami sangat jarang mentracing kontak eratnya diluar keluarganya sendiri...” (P12)

Kemudian peneliti melakukan cross cek dengan Dinas Kesehatan tentang kendala yang biasa dihadapi puskesmas. Dinas kesehatan menyatakan memang petugas puskesmas mengalami kesulitan mengidentifikasi kontak erat penderita. Hal ini bisa terlihat dari aplikasi pelaporan yang ada di Dinas Kesehatan. Pada tahap awal, puskesmas tidak menginput data kontak erat pasien. Sekarang, puskesmas hanya menginput data kontak serumah. Tetapi karena data diakumulasi dari awal kasus timbul, sehingga walaupun sekarang hampir semua kasus konfirmasi memiliki data kontak serumah, namun angka rasio kontak konfirmasi adalah $1: 1(0,75)$

“...Setiap hari petugas surveilans puskesmas itu akan mengisi laporan harian agregat. Kalau yang terkait dengan kontak erat ya berapa kasus konfirmasi yang sudah dilakukan pelacakan, berapa kontak erat baru, berapa kontak erat sudah selesai isolasi dan berapa kontak erat yang berubah menjadi kasus konfirmasi. Dari sini akan direkap oleh dinas kesehatan. Makanya kami bisa ada datanya dan tau, kinerja pelacakan kontak erat ini masih jauh sekali dari target. Banyak keluhan dari puskesmas yang sudah disampaikan ke kami sewaktu kami bimtek atau lewat wa grup, mereka kesulitan mendapatkan kejujuran dari kasus konfirmasi yang sedang dilacak...”(P2).

Kendala lain adalah alamat atau nomor telepon kasus konfirmasi tidak jelas atau palsu. Data notifikasi kasus konfirmasi yang dikeluarkan oleh Dinas Kesehatan berasal dari dua jenis sumber yang berbeda, 
yaitu dari Puskesmas dan dari RS atau faskes lainnya. Menurut petugas surveilans, data rilis yang berasal dari RS yang sering menjadi permasalahan terkait data alamat yang tidak lengkap, tidak ada nomor telepon atau alamat maupun nomor telepon palsu.Petugas puskesmas akan meminta bantuan kepada lurah atau RT untuk mengkonfirmasi data alamat yang tidak jelas. Ini biasanya memakan waktu lebih dari satu hari, sehingga pelacakan kontak terlambat dilakukan. Berikut cuplikan wawancara mendalam petugas puskesmas :

“.....Macem ini nah (sambil memperlihatkan pencatatan di buku bantu), dak ado alamat, dak ado nomor telepon, dak ado RT....(P12)

“....Macem ini kan, feri, dio memakai tiga alamat (sambil memperlihatkan buku bantu), alamat swabnya sumur tinggi, di rumah sakit, dio pake alamat kito, istrinyo pake alamat yang lamo, tempat emak bapaknyo, telpon mati, mati galo-galo suami istri, dari tanggal, dari hari minggu......"(P12)

Kendala keterlambatan pelacakan kontak yang berikutnya adalah pasien tidak kooperatif saat dihubungi petugas, baik melalui telepon maupun melalui kunjungan rumah. Petugas tidak dapat melacak kontak dan malahan mendapatkan ancaman serta kata-kata kasar dari pasien.

“....kalo soal di ancam pasien saat kita baru pertama menghubungi itu sering bu, pasien berkata-kata kasar supaya kita tidak usah memantau isolasi mereka. Mereka tidak mau masyarakat sekeliling tau...."(P11)

“....ada juga pasien yang kami telepon, marahmarah sewaktu diberitahu hasil lab nya positif... Kita malah dituduh pasien, sengaja mempositifkan hasilnya supaya bisa mencairkan dana insentif. Ada juga pejabat-pejabat yah, kami kesulitan menghadapinya, karena ngangkat telepon pun tidak mau....." (P13).

Dalam pelaksanaan pemantauan isolasi mandiri terdapat ketidakkonsistenan dalam pemantauan. Untuk beberapa kasus, petugas belum berhasil mengawasi kepatuhan isolasi mandiri dirumah. Penyebab utama ketidakpatuhan pasien isolasi mandiri adalah untuk pemenuhan kebutuhan makan minum dan kebutuhan dasar lainnya dikarenakan tidak ada uang atau tidak ada yang membelikan. Apalagi kontak erat yang melaksanakan isolasi tersebut adalah orang tanpa gejala (OTG). Mereka mengaku keluar rumah dengan tetap menjalankan protokol kesehatan agar tidak menularkan orang sekeliling. Berikut cuplikan wawancara mendalam dengan petugas surveilans puskesmas :
"Pernah juga kita menerima laporan dari warga, bahwa pasien yang positif tersebut masih keluar rumah. Pernah ada pengalaman seperti itu, jadi saya langsung telepon pasien, jawaban pasien, bagaimana mereka mau membeli bahan makanan kalau tidak keluar? Tapi pasien mengaku kan sudah pakai masker, bagi pasien tidak apa-apa keluar ruang isolasi asalkan memakai masker... (P13)

Selain itu, ketidakkonsistenan pelaksanaan isolasi mandiri terkait dengan pemeriksaan PCR pada kontak erat dan suspek. Perubahan pedoman revisi 5 dalam syarat penentuan pemeriksaan PCR hanya kepada orang yang bergejala saja atau suspek saja. Hal ini berpengaruh pada kepatuhan kontak erat dan suspek dalam melaksanakan anjuran untuk melakukan isolasi. Kontak erat tanpa gejala yang tidak di swab merasa tidak perlu melakukan isolasi atau karantina. Hal ini diuraikan dari hasil wawancara dengan petugas surveilans Puskesmas sebagai berikut :

“.....Pedoman revisi 5 ini kan tidak menganjurkan untuk swab seluruh kontak erat seperti di revisi 4 dulu bu. Yang di swab hanya yang bergejala saja. kalau tidak bergejala, kami anjurkan untuk isolasi mandiri saja selama 14 hari, akan kami pantau, dan kalau sudah selesai dianggap sudah selesai. Kalau di pedoman kan seperti itu...." (P9).

Hasil wawancara tersevut sejalan dengan observasi yang dilakukan oleh penliti bahwa kegiatan penelusuran kontak tidak terjadi

Tabel 4. Hasil Observasi Pelacakan Kontak

\begin{tabular}{|l|l|l|l|}
\hline 1 & $\begin{array}{l}\text { Adanya kegiatan identifikasi } \\
\text { kontak erat melalui telepon }\end{array}$ & $\mathrm{V}$ & \\
\hline 2 & $\begin{array}{l}\text { Adanya kegiatan } \\
\text { penelusuran kontak melalui } \\
\text { telepon }\end{array}$ & $\mathrm{X}$ & $\begin{array}{l}\text { Tidak ditemukan } \\
\text { kontak lain selain } \\
\text { data yang serumah } \\
\text { sehingga tidak ada } \\
\text { data nomor telepon } \\
\end{array}$ \\
& $\begin{array}{l}\text { lain selain nomor } \\
\text { telepon kasus } \\
\text { konfirmasi. }\end{array}$ \\
\hline
\end{tabular}

Berdasarkan hasil penelitian tersebut dapat diketahui bahwa terjadi ketidakkonsistenan dalam pelacakan kontak yang dilakukan oleh Puskesmas. Petugas surveilans puskesmas tidak berhasil mengidentifikasi kontak erat selain kontak serumah penderita dikarenakan beberapa faktor yang pertama ketidakjujuran pasien, stigma masyarakat, data rilis kasus terlambat, alamat/ no telpon tidak jelas, pasien tidak kooperatif serta perubahan pedoman yang terjadi dari revisi 4 ke revisi 5. Dalam hal ini perintah yang diberikan kepada pelaksana untuk melaksanakan suatu kebijakan memerlukan sebuah komunikasi yang harus 
konsisten dan jelas. Apabila suatu perintah sering berubah-ubah, dapat memicu terjadinya kebingungan bagi pelaksana dalam pelaksanannya. Selain itu, perintah pelaksanaan suatu kebijakan yang berubah-ubah akan mendorong implementator mengambil langkah tindakan yang sangat longgar dalam melaksanakan kebijakan tersebut. Apabila hal ini terjadi, maka dapat berdampak pada ketidakefektifan pelaksanaan kebijakan sebab tindakan yang sangat longgar memungkinan tidak dapat digunakan untuk melaksanakan tujuan-tujuan dari kebijakan.

\section{Pembahasan}

\section{Transmisi}

Internet yang tidak dibatasi jarak dan waktu membuat sosialisasi dapat dilakukan kapan saja dan di mana saja, penggunaan internet sebagai sarana sosialisasi dapat memberikan dampak yang positif dan negatif. Sebagai dampak positif, petugas Puskesmas dapat mengikuti sosialisasi melalui zoom meeting yang diselenggarakan oleh berbagai narasumber, waktu pelaksanaanpun lebih fleksibel sehingga banyak dilaksanakan diluar jam kerja Puskesmas.

Transmisi informasi dan intensitas sosialisasi ke masyarakat dirasakan cukup sulit. Puskesmas hanya mengandalkan media sosial seperti instagram atau facebook puskesmas maupun media sosial milik pribadi petugas untuk mensosialisasikan tentang penanggulangan COVID-19 kepada masyarakat. Sehingga informasi yang sampai ke masyarakat tergantung pada banyaknya masyarakat yang mengakses media sosial puskesmas dan petugas tersebut. Pada saat wabah virus corona menimpa Indonesia, keadaan negara belum siap untuk menghadapinya, sehingga reaksi cepat sosialisasi pencegahan belum sempat dilakukan oleh Indonesia. Penerapan komunikasi risiko kemasyarakat yang memadukan unsur kecepatan dan akurasi sangat penting dalam mencegah penularan virus Corona.

Dengan tingkat persepsi, pengetahuan, sikap dan perilaku masyarakat yang baik diharapkan masyarakat akan secara mandiri melindungi diri dari penyebaran COVID-19. Hasil penelitian Ferdous et al(2020) pada masyarakat Bangladesh, menghasilkan faktor sosiodemografi seperti jenis kelamin perempuan, usia lebih tua, pendidikan tinggi, pekerjaan, pendapatan bulanan keluarga, tempat tinggal diperkotaan, merupakan faktor untuk lebih sering melakukan tindakan pencegahan(Ferdous et al. 2020). Tingkat pengetahuan pun akan tinggi apabila masyarakat menyadari tingkat bahaya dari COVID-19. Penelitian pertama tentang pengetahuan, sikap dan tindakan masyarakat di China, dilakukan saat insiden COVID-19 sangat tinggi di negara tersebut menyatakan bahwa program pendidikan kesehatan yang bertujuan untuk meningkatkan pengetahuan tentang COVID-19 sangat membantu untuk penduduk Tionghoa memiliki sikap optimis dan mempertahankan praktik pencegahanyang tepat(Zhong et al. 2020)

Sosialisasi Puskesmas dan Dinas Kesehatan ke masyarakat lebih banyak tentang mematuhi protokol kesehatan, sangat jarang bahkan tidak pernah mensosialisasikan tentang pelacakan kontak erat dan isolasi mandiri. Hal ini mengakibatkan stigma yang sangat tinggi di masyarakat. Penolakan masyarakat saat petugas kesehatan melakukan pelacakan kontak erat masih sangat tinggi. Intensitas atau transmisi informasi ke masyarakat terkait pelacakan kontak dan isolasi mandiri masih sangat sedikit. COVID-19 adalah penyakit baru dengan banyak hal yang belum diketahui. Faktor-faktor yang tidak diketahui ini telah menimbulkan kecemasan di kalangan masyarakat, yang pada gilirannya memicu stigma dan diskriminasi (Abdelhafiz and Alorabi 2020).

Masyarakat merupakan garda terdepan penentu keberhasilan penanggulangan COVID-19. Peningkatan pengetahuan tentang COVID-19 diperlukan untuk mengubah perilaku masyarakat dengan perubahan persepsi dan sikap yang lebih baik. Oleh karena itu diperlukan intensitas sosialisasi yang tinggi pada penerapan komunikasi risiko dan pemberdayaan masyarakat (KRPM) yang efektif. KRPM dapat membantu mencegah infodemic (penyebaran informasi yang salah/hoaks), membangun kepercayaan publik terhadap kesiapsiagaan dan respon pemerintah sehingga masyarakat dapat menerima informasi dengan baik dan mengikuti anjuran pemerintah. Dengan demikian, halhal tersebut dapat meminimalkan kesalahpahaman dan mengelola isu/hoaks terhadap kondisi maupun risiko kesehatan yang sedang terjadi(Kementrian Kesehatan RI 2020). Komunikasi risiko ini diperlukan agar bisa terbangun kepercayaan, informasi cepat disampaikan, untuk mengkomunikasikan ketidakpastian kepada masyarakat, untuk berkoordinasi dengan semua pihak yang terlibat, untuk mengutamakan dan mengupayakan transparansi, proaktif dan melibatkan berbagai pemangku kepentingan (Kementrian Kesehatan RI 2020).

Masyarakat membutuhkan media yang lebih komunikatif seperti penyuluhan langsung dari tokoh masyarakat yang berasal dari masyarakat itu sendiri. Dari penelitian kolaborasi yang dilakukan Departemen Ilmu Komunikasi Universitas Indonesia dan Savica Consultancy, menunjukkan sebesar 31,50 persen masyarakat memilih kelompok RT/RW sebagai tempat pilihan mendapatkan informasi tentang pandemi Covid19. Kelompok RT/RW ini berada di posisi kelima dipilih oleh masyarakat setelah kelompok aparat dan instansi pemerintah $(69,80 \%)$, tenaga kesehatan $(64,40 \%)$, tokoh masyarakat $(42,10 \%)$, dan kelompokak ademisi/lembaga penelitian $(34,20 \%)$.

Komunikasi resiko kepada masyarakat sangat berperan dalam penerimaan masyarakat untuk pelacakan kontak dan pelaksanaan isolasi mandiri. Masyarakat 
lebih banyak menerima himbauan melaksanakan protocol kesehatan diberikan pengertian mengapa hal itu harus dilakukan dan seberapa pentingnya peranan masyarakat dalam penanggulangan pandemic COVID19 ini. Pengujian komprehensif dan rencana pelacakan kontak membutuhkan pemikiran kedepan, koordinasi, komunikasi, dan penerimaan sosial yang tinggi agar dapat dilaksanakan secara efektif. Rencana yang kuat, didukung oleh sumber daya yang besar (yaitu, keuangan, sumber daya manusia, hukum, dan teknologi), dikombinasikan dengan kepatuhan yang tinggi terhadap rekomendasi jarak fisik dan penggunaan masker, telah berperan dalam mitigasi COVID-19 di banyak negara, termasuk negara dengan wilayah yang memiliki kepadatan populasi yang sangat tinggi (Hagan et al. 2020).

\section{Kejelasan}

Pandemi COVID-19 merupakan pengalaman wabah penyakit infeksi terbesar yang pernah dialami oleh petugas kesehatan. Petugas belum mempunyai pengetahuan tentang COVID-19 sebelumnya karena ini penyakit yang baru muncul didunia di akhir Desember 2019. Diperlukan penambahan pengetahuan petugas kesehatan terutama petugas Puskesmas yang merupakan garda terdepan penanggulangan penyebaran COVID-19 melalui tindakan promotif dan preventif. Kejelasan dari sosialisasi dan informasi bagi petugas puskesmas merupakan kunci dalam petugas melakukan tindakan penanggulangan COVID-19.

Dimensi kejelasan, menghendaki agar kebijakan yang ditransmisikan kepada pelaksana, target grup dan pihak lain yang berkepentingan dapat diterima petugas secara jelas sehingga dapat mengetahui apa yang menjadi maksud, tujuan, sasaran, serta substansi dari kebijakan publik tersebut. Setiap petugas harus mengetahui apa yang harus dipersiapkan serta dilaksanakan untuk mensukseskan kebijakan tersebut secara efektif dan efisien.

Pelaksanaan pelacakan kontak erat dan pemantauan isolasi mandiri penderita covid-19 dibutuhkan pedoman dan panduan yang khusus agar kegiatan tersebut dapat dilaksanakan secara masif, cepat, efektif dan terkoordinasi. Maka, pedoman tersebut harus disosialisasikan dengan baik dengan petugas yang terkait. Dari hasil penelitian, sosialisasi yang intens melalui zoom meeting secara kuantitas belum berpengaruh secara signifikan terhadap tingkat pengetahuan petugas puskesmas. Untuk meningkatkan pengetahuan secara umum, petugas puskesmas harus mencari secara mandiri diluar zoom meeting dan sosialisasi melalui grup whatsapp oleh Dinas Kesehatan Kota Palembang. Penelitian di Northwest Euthopia, menyatakan bahwa $98 \%$ petugas kesehatan mendapatkan informasi tentang COVID-19 dari media massa seperti televisi dan radio. Lebih dari $64 \%$ partisipan mengakses website Federal Ministry ofHealth (FMOH), WHO
danCenter for Disease Control (CDC) (Kassie et al. 2020).

Sosialisasi melalui zoom meeting tidak efektif dan berpengaruh pada kejelasan materi yang disampaikan pada petugas Kesehatan.Dari hasil penelitian, factor yang mempengaruhi ketidakjelasan tersebut adalah karena petugas puskesmas tidak focus mengikuti materi yang disampaikan apabila pertemuannya dilakukan pada jam kerja. Banyak pekerjaan yang dapat dilakukan sambil mengikuti zoom meeting. Hal ini kemungkinan disebabkan peserta zoom meeting yang diikuti oleh puskesmas jumlahnya sangat banyak, sehingga tidak terjalin kedekatan dengan narasumber. Tidak terjadi komunikasi dua arah, sehingga seperti menonton televise atau mendengarkan radio. Berbeda dengan hasil penelitian Monica (2020) tentang efektifitas penggunaan zoom meeting pada pembelajaran online pada mahasiswa, menghasilkan sistem pembelajaran yang efektif. Mahasiswa dapat fokus, lebih cepat mengerti dan lebih berani mengungkapkan pendapat dikarenakan tidak bertemu secara fisik langsung dengan dosen (Monica and Fitriawati 2020).

Ketidakjelasan petugas akan materi yang disampaikan saat sosialisasi, membuat pemahaman yang berbeda antara petugas Kesehatan terutama dalam pelacakan kontak. Penyebab dalam keterlambatan pelacakan kontak terjadi karena beberapa factor yaitu kurangnya pemahaman petugas saat sosialisasi yang telah disampaikan, kurangnya keterampilan petugas karena tidak diberikan pelatihan, rendahnya tingkat pengetahuan masyarakat karena kurangnya sosialisasi ke masyarakat, dan kurangnya fasilitasi serta kapasitas dari pemerintah.

Permasalahan dilapangan adalah petugas belum ada pengalaman sebelumnya, sehingga perlu segera diberikan pengarahan dan pelatihan. Sosialisasi dan pelatihan dari tim gerak cepat penanggulangan wabah ini sangat diperlukan karena pandemi COVID-19 ini merupakan hal yang baru yang belum pernah dialami oleh petugas. Tetapi petugas menghadapi tantangan selama pandemi COVID-19 tidak dapat mengadakan pertemuan tatap muka secara langsung. Penggunaan tehnologi menjadi peluang meningkatkan komunikasi dan koordinasi. Bagaimana untuk menyakinkan publik apabila implementor kebijakan penanggulangan COVID-19 sendiri tidak terinformasi dengan jelas mengenai kondisi dan strategi penanggulangan COVID19.

Selain itu, penguatan tim puskesmas belum pernah dilakukan karena evaluasi pelaksanaan kegiatan belum pernah dilakukan oleh Dinas Kesehatan kepada Puskesmas. Puskesmas belum paham pentingnya menemukan kontak erat dari setiap kasus konfirmasi dan pentingnya segera mengisolasi kontak erat tersebut. Puskesmas belum memahami bahwa tidak mungkin seluruh kasus terkonfirmasi tidak mempunyai kontak erat selain kontak serumahnya. Hal ini dikarenakan 
Puskesmas Palembang sebagai ujung tombak pemerintah Kota Palembang untuk melakukan kegiatan pelacakan kontak belum pernah dilatih dan dievaluasi kinerjanya.

\section{Konsistensi}

Pelacakan kontak adalah proses mengidentifikasi, menilai, dan mengelola orang yang telah terpapar suatu penyakit (kontak) untuk mencegah penularan selanjutnya. Sesuai pedoman revisi 5 , pelacakan kontak terdiri atas tiga tahapan yaitu identifikasi kontak, penelusuran kontak dan pengelolaan kontak (Kementrian Kesehatan RI 2020). Kegiatan pelacakan kontak COVID-19 di Kota Palembang dimulai setelah petugas surveilans puskesmas mendapatkan notifikasi kasus terkonfirmasi positif dari Dinas Kesehatan melalui grup whatsapp. Pasien dihubungi pertama kali oleh petugas surveilans untuk menyampaikan hasil pemeriksaan RTPCR dan segera dilakukan Penyelidikan Epidemiologi (PE). Dalam pelaksanaan PE, pelacakan kontak mulai dilakukan dengan mengidentifikasi kontak erat kasus konfirmasi tersebut (Kementrian Kesehatan RI 2020)

Target dari pelaksanaan pelacakan kontak erat adalah mendeteksi lebih dari $80 \%$ kontak erat dari kasus terkonfirmasi dalam waktu 72 jam dan dapat mengisolasi $80 \%$ dari seluruh kontak erat yang telah teridentifikasi(Kementrian Kesehatan RI 2020). Dari penelitian ini, petugas Puskesmas telah melaksanakan pelacakan kontak hampir pada seluruh kasus konfirmasi dalam waktu kurang dari 72 jam semenjak notifikasi dari Dinas Kesehatan diterima oleh petugas surveilans Puskesmas. Namun terdapat ketidakkonsistenan petugas puskesmas dalam melakukan identifikasi kontak dan terdapat beberapa hambatan yang menyebabkan keterlambatan dalam pelacakan kontak.

Dari hasil Penelitian, petugas kesulitan untuk menggali informasi dari pasien terkonfirmasi. Pasien tidak mau jujur siapa saja kontak mereka bahkan pasien tidak kooperatif tidak mau mengangkat telepon bila dihubungi dan tidak bersedia dikunjungi dirumah. Hal ini sejalan dengan hasil Penelitian dari Lash et al(2020) dilaporkan dari negara bagian Amerika Serikat (AS) dengan kinerja staf departemen kesehatan yang tinggi dalam pelacakan kontak mendapatkan hasil masih terdapat yaitu di Maryland sebanyak 50\%, New Jersey sebanyak 52\%, Randolph County 35\% dan Mecklenburg County $48 \%$ dari kasus konfirmasi melaporkan tidak mempunyai kontak erat. Dari kontak erat yang telah teridentifikasi, terdapat 25\% di Mecklenburg dan 48\% di Randolph kontak erat yang tidak berhasil dihubungi melaluitelepon(Lash et al. 2020)

Stigma yang tinggi dimasyarakat membuat sebagian kecil orang yang diperiksa swab PCR memberikan alamat atau nomor telepon palsu, sehingga petugas tidak bisa menghubungi sewaktu hasil swab RTPCR sudah keluar. Beberapa kasus konfirmasi ini tidak dapat dihubungi sehingga tidak dilakukan pelacakan kontak. Secara nasional jumlah presentase kasus konfirmasi dilacak kontak erat hamper mendekati target, yakni 77,8 persen dengan target 80 persen. Artinya, dari 100 orang yang terkonfirmasi positif, 77,8 orang sudah dilacak kontak eratnya. Sisanya belum dapat dilakukan pelacakan kontak karena tidak dapat menghubungi kasus konfirmasi tersebut. Pemantauan terhadap kontak erat juga tidak menunjukkan hasil yang memuaskan. Data menunjukkan pemantauan terhadap kontak erat memiliki rasio 37,8 persen. Padahal, jumlah target untuk pemantauan kontak erat adalah di atas 80 persen.

Oleh karena itu, pelibatan masyarakat juga sangat penting untuk memastikan tidak adanya stigma yang muncul pada orang-orang yang masuk kategori kontak erat.Komunikasi dengan publik sangatlah penting.Komunikasi risiko harus secara pararel disampaikan kepada masyarakat untuk mencegah hal-hal yang tidak diinginkan seperti munculnya stigma dan diskriminasi akibat ketidaktahuan(Kementrian Kesehatan RI 2020). Keterlibatan publik dengan penyelidik kasus dan pelacak kontak dapat melindungi teman, keluarga, dan anggota komunitas dari potensi infeksi. Pejabat publikdan tokoh masyarakat perlu dilibatkan dan mendukung penyelidikan kasus dan upaya pelacakan kontak. Dibutuhkan kesadaran publik, pemahaman dan penerimaan investigasi kasus dan pelacakan kontak dan kebutuhan akan kontak untuk memisahkan diri dari orang lain yang tidak terekspos(CDC 2020).

Pelacakan kontak yang berhasil akan mengharuskan kasus dan kontak menerima panggilan telepon dari pelacak kontak. Dari hasil penelitian masih banyak ditemukan kasus konfirmasi yang tidak kooperatif, yang tidak mengangkat telepon petugas maupun tidak mau ditemui melalui kunjungan rumah. Studi di Amerika Serikat menyatakan bahwa kebanyakan orang mungkin tidak akan menjawab panggilan dari nomor yang tidak mereka kenali. Privasi adalah masalah lain dari sebagian besar orang Amerika, dan beberapa kasus positif mungkin tidak setuju untuk membagikan nama dan nomor kontak dekat mereka. Kontak juga mungkin tidak mematuhi rekomendasi karantina dari pelacak kontak (Pfefferbaum and North 2020).

Selain itu dari hasil penelitian, terdapat beberapa kendala keterlambatan keluarnya hasil RT-PCR yang akhirnya menyebabkan keterlambatan dalam pelacakan kontak. Yang pertama karena disebabkan kapasitas maksimal pemeriksaan di laboratorium telah terlampaui. Hal ini terjadi saat terdapat lonjakan kasus COVID-19. Yang kedua, keterlambatan disebabkan keterlambatan pihak Rumah Sakit menginput data pengiriman sampel swab PCR ke aplikasi all record sehingga laboratorium pemeriksa (BBLK) tidak dapat menginput hasil dari pemeriksaan. Hasil RT-PCR paling cepat keluar dalam 3 hari dan paling lama keluar dalam 10 hari sehingga waktu selesai isolasi sudah terlampai. Akibatnya petugas tidak mengisi laporan pemantauan isolasi kasus 
konfirmasi tersebut secara real time. Suatu studi menggunakan model matematika menyatakan bahwa keterlambatan mendapatkan hasil test antara waktu timbul gejala sampai didapatkan hasil test swab PCR merupakan factor utama yang mempengaruhi efektifitas pelaksanaan pelacakan kontak. Pelacakan kontak tidak akan berhasil mencegah penyebaran kasus apabila keterlambatan lebihd ari 7 hari (Kretzamar et al. 2020)

Setelah tahap penelusuran kontak dilakukan, maka tahap selanjutnya adalah pemantauan isolasi atau karantina kontak. Isolasi mandiri atau perawatan di rumah dilakukan terhadap orang yang bergejala ringan dan tanpa kondisi penyerta seperti (penyakit paru, jantung, ginjal dan kondisi immunocompromise).Penting untuk memastikan bahwa lingkungan tempat isolasi kondusif untuk memenuhi kebutuhan fisik, mental, dan medis yang diperlukan orang tersebut.Pemantauan isolasi di rumah menjadi tanggung jawab petugas kesehatan di Puskesmas setempat. Setiap kontak erat yang dipantau setiap hari wajib diperiksa suhu tubuhnya dan gejala yang mungkin dikeluhkan. Hasil pemantauan harian dituliskan di dalam formulir yang disediakan, kemudian dilaporkan secara harian kepada Dinas Kesehatan Kabupaten/Kota untuk selanjutnya dilakukan rekap ke dalam Laporan Harian Agregat (Kementrian Kesehatan RI 2020).

Studi dari Webster(2020) menyatakan ada sembilan faktor yang mempengaruhi tingkat kepatuhan karantina atau isolasi yaitu karakteristik demografi dan pekerjaan, faktor sosial budaya (norma sosial,nilai budaya dan hukum), pengetahuan tentang wabah penyakit menular dan protokol karantina, manfaat karantina yang dirasakan, orang yang menganggap bahwa mereka lebih beriso untuk tertular dan menjadi parah, kepraktisan karantina, pengalaman dan keyakinan akan petugas kesehatan dan fungsi pusat kesehatan, lamanya waktu untuk karantina, kepercayaan kepada pemerintah (Webster et al. 2020).

Hasil penelitian yang mempengaruhi kepatuhan isolasi di Kota Palembang sejalan dengan beberapa penelitian sebelumnya. Penelitian saat outbreak SARS 2003 di Toronto menyatakan keperluan untuk bekerja dan takut kehilangan pendapatansebagai alasan untuk tidak mematuhi protokol karantina (DiGiovanni et al. 2004). Studi lain pada swine flumenyebutkan faktorfaktor yang berkaitan dengan keberlangsungan kehidupan di luar karantina sebagai alasan untuk tidak mematuhi karantina. Contohnya termasuk kebutuhan untuk menghadiri acara penting atau mengunjungi keluarga dan teman (Teh et al. 2012). Suatu studi saat outbreak ebola menyatakan penderitamelanggar karantina untuk mendapatkan perbekalan atau untuk mencari pertolongan medis (Pellecchia et al. 2015). Terkadang faktor-faktor yang berkaitan dengan situasi rumah tangga selama karantina mempengaruhi kepatuhan. Hal ini dapat terjadi karena orang-orang disibukkan dengan kesehatan orang yang dicintai yang buruk, sehingga mereka sendiri tidak mematuhi protokol karantina (Cava et al. 2005). Demikian pula, jika anakanak yang dikarantina dapat dirawat oleh orang dewasa di dalam rumah daripada oleh keluarga luar, teman atau bantuan sewaan yang datang ke rumah, ini memudahkan keluarga untuk mematuhi protokol karantina(McVernon et al. 2011).

Dari hasil penelitian, informan menyatakan tidak pernah mendapatkan evaluasi dari Dinas Kesehatan. Data-data epidemiologi dan surveilans hanya dibagikan ke puskesmas melalui grup whatsapp dan puskesmas akan menganalisa sendiri data tersebut sehingga tergantung dengan kemampuan analisa masing-masing puskesmas. Sebagian besar puskesmas tidak mempunyai epidemiolog sehingga puskesmas tidak bisa menilai capaian kinerja yang telah dilakukan puskesmas berdasarkan data-data yang telah dibagikan Dinas Kesehatan tersebut. Hal ini sejalan dengan studi yang dilakukan di Amerika Serikat untuk menganalisa kegagalan penanggulangan pandemi COVID-19 di Amerika Serikat, menyatakan bahwa kegagalan tersebut disebabkan kekurangan dalam infrastruktur kesehatan masyarakat. Praktisi kesehatan masyarakat dan ilmuwan harus mengakui kompleksitas upaya pelacakan dan pengujian dan mempromosikan kebijakan baru yang bertujuan untuk mengurangi penularan komunitas yang berkelanjutan (Clark, Chiao, and Amirian 2020).

\section{SIMPULAN}

Kesimpulan yang didapat dalam penelitian ini, yaitu :

1. Kurangnya sosialisasi yang dilakukan terkait dengan pedoman pencegahan maupun pelacakan kontak dan isolasi mandiri penderita covid-19.

2. Sosialisasi yang dilakukan melalui virtual tidak efektif sehingga menyebabkan ketidakjelasan komunikasi yang disampaikan berhubungan dengan pelaksanaan kebijakan.

3. Terjadi ketidakkonsistenan dalam pelacakan kontak yang dilakukan oleh Puskesmas dikarenakan beberapa faktor yang pertama ketidakjujuran pasien, stigma masyarakat, data rilis kasus terlambat, alamat/ no telpon tidak jelas, pasien tidak kooperatif serta perubahan pedoman yang terjadi dari revisi 4 ke revisi 5.

\section{DAFTAR PUSTAKA}

Abdelhafiz, Ahmed Samir, and Mohamed Alorabi. 2020. "Social Stigma: The Hidden Threat of COVID19." Frontiers in Public Health 8(August).

Cava, Maureen A et al. 2005. "Risk Perception and Compliance With Quarantine During the SARS Outbreak." Journal of Nursing Scholarship 37(4): 343-47. $\quad$ https://doi.org/10.1111/j.15475069.2005.00059.x.

CDC. 2020. "Case Investigation and Contact Tracing: Part of a Multipronged Approach to Fight the 
COVID-19 Pandemic." : 23-25. https://www.cdc.gov/coronavirus/2019ncov/downloads/php/principles-contact-tracingbooklet.pdf.

Clark, Eva, Elizabeth Y Chiao, and E Susan Amirian. 2020. "Why Contact Tracing Efforts Have Failed to Curb Coronavirus Disease 2019 (COVID-19) Transmission in Much of the United States." Clinical Infectious Diseases 2019(Xx Xxxx): 1-5.

DiGiovanni, Clete, Jerome Conley, Daniel Chiu, and Jason Zaborski. 2004. "Factors Influencing Compliance with Quarantine in Toronto during the 2003 SARS Outbreak." Biosecurity and bioterrorism: biodefense strategy, practice, and science 2(4): 265-72.

Dorigatti, I., Okell, L., Cori, A., Imai, N., Baguelin, M., Bhatia, S., \& Boonyasiri, A. (2020). Severity of 2019-novel coronavirus ( $\mathrm{nCoV}$ ). In Imperial College London COVID-19 Response Team. https://doi.org/10.25561/77154

Edward III, G. C. (1980). Implementing Public Policy. Washington: Congressional Quarterly Press.

Ferdous, Most Zannatul et al. 2020. "Knowledge, Attitude, and Practice Regarding COVID-19 Outbreak in Bangladesh: An Onlinebased CrossSectional Study." PLoS ONE 15(10 October): 117.

http://dx.doi.org/10.1371/journal.pone.0239254.

Hagan, John Elvis et al. 2020. “Africa's COVID-19 Situation in Focus and Recent Happenings: A Mini Review." Frontiers in Public Health 8(December).

Kassie, Belayneh Ayanaw et al. 2020. "Knowledge and Attitude towards COVID-19 and Associated Factors among Health Care Providers in Northwest Ethiopia." PLOS ONE 15(8 august): 112.

http://dx.doi.org/10.1371/journal.pone.0238415.

Kretzamar, E Mirjam et al. 2020. "Impact of Delays on Effectiveness of Contact Tracing Strategies for COVID-19: A Modelling Study." Lancet Public Health 5(January): e452-59.

Lash, R. Ryan et al. 2020. "COVID-19 Contact Tracing in Two Counties - North Carolina, June-July 2020." MMWR. Morbidity and Mortality Weekly Report 69(38): 1360-63.

Lee, V. J., Chiew, C. J., \& Khong, W. X. (2020). Interrupting transmission of COVID-19: lessons from containment effort in Singapore. Jurnal Travel Medicine, 1-7. https://doi.org/10.1093/jtm/taaa039

Lu, R., Zhao, X., Li, J., Niu, P., Yang, B., Wu, H., ... Tan, W. (2020). Genomic characterisation and epidemiology of 2019 novel coronavirus: implications for virus origins and receptor binding. The Lancet, 395(10224), 565-574. https://doi.org/10.1016/S0140-6736(20)30251-8
McVernon, Jodie et al. 2011. "Recommendations for and Compliance with Social Restrictions during Implementation of School Closures in the Early Phase of the Influenza A (H1N1) 2009 Outbreak in Melbourne, Australia." BMC Infectious Diseases 11(1): 257. https://doi.org/10.1186/14712334-11-257.

Menteri Kesehatan RI. (2020). SE_MENKES_202_2020_protokol_isolasi_diri_C OVID.pdf.

Monica, Junita, and Dini Fitriawati. 2020. "Efektivitas Penggunaan Aplikasi Zoom Sebagai Media Pembelajaran Online Pada Mahasiswa Saat Pandemi Covid-19." Jurnal Communio : Jurnal Jurusan Ilmu Komunikasi 9(2): 1630-40.

Pellecchia, Umberto et al. 2015. "Social Consequences of Ebola Containment Measures in Liberia." PLOS ONE 10(12): e0143036. https://doi.org/10.1371/journal.pone.0143036.

Pfefferbaum, Betty, and Carol S North. 2020. "Mental Health and the Covid-19 Pandemic." New England Journal of Medicine 383(6): 510-12.

Teh, Benjamin et al. 2012. "Impact of Swine Influenza and Quarantine Measures on Patients and Households during the H1N1/09 Pandemic." Scandinavian Journal of Infectious Diseases 44(4): 289-96. https://doi.org/10.3109/00365548.2011.631572.

Webster, R K et al. 2020. "How to Improve Adherence with Quarantine : Rapid Review of the Evidence." (January).

World Health Organization. (2019). Mers Situation Update November 2019. World Health Organization Eastern Mediterranean Regional Office (EMRO), (November), 22765492. Retrieved from.

World Health Organization. (2020). Laboratory testing for coronavirus disease 2019 (COVID-19) in suspected human cases.

Zhong, Bao Liang et al. 2020. "Knowledge, Attitudes, and Practices towards COVID-19 among Chinese Residents during the Rapid Rise Period of the COVID-19 Outbreak: A Quick Online CrossSectional Survey." International Journal of Biological Sciences 16(10): 1745-52 